\title{
Analysis of Financial Literacy Amongst Indonesian First- Semester Students: A Study in Universitas Indonesia, Institut Pertanian Bogor and Institut Teknologi Bandung
}

\author{
Pinesti Zanariasti ${ }^{1}$, Novita Ikasari ${ }^{2}$ \\ zanariasti@gmail.com ${ }^{1}$,novita.ikasari@yahoo.com ${ }^{2}$ \\ Faculty of Administrative Science, Universitas Indonesia
}

\begin{abstract}
In the advent of digital economy era, financial literacy is considered the crux to achieve financial inclusion. The existing body of knowledge pivots around personal finance and investment opportunities with a handful highlighting the influence of socioeconomic variables on financial literacy in young adults. This study aims at determining the financial literacy level of first-year students at selected Indonesian public universities with consideration to different disciplines of the respondents which might shape their financial literacy. Financial literacy is measured by financial attitude, behaviour, and knowledge. This study uses quantitative approach whereby survey data from 389 respondents are analysed and presented in descriptive statistics. The result shows that students with low financial literacy outnumber those with high literacy level in all three universities. A pattern exists with regard to the different study discipline and in general, female students are relatively equally distributed between high and low financial literacy group.
\end{abstract}

Keywords: financial literacy, financial attitude, financial behaviour, financial knowledge.

\section{Introduction}

The wave of digital economy and its impact on socio-economic are at the centre of scholarly discussion within the last years although the concept itself was coined in late $20^{\text {th }}$ century. Tapscott (1995) identified one of the challenges brought by digitation of economics concerns with access disparity to social and financial means [1]. The different scale of business, industry and infrastructures has created different learning curve across the world, which gives rise to the importance of financial inclusion. Government and industries alike have incorporated financial technology into their system as a mean to achieve full inclusion. In this context, Ozili (2018) discussed the benefits and challenges posed by digital finance which discussed the technical and infrastructure issues whilst underlined the lack of financial literacy as a disincentive for digital finance provider [2]. Previous study conducted by Oliver Wyman and Microsave for the Asian Development Bank in 2016 also found that the effective use of digital finance depended on financial literacy level of the targeted group [3]. Thus, it can be concluded that financial literacy plays a strategic role in efforts towards financial inclusion and, at a larger scale, national economy. 
Financial literacy is understood as the mastery of a set of knowledge, attitudes, and behaviours that enable people to make responsible decisions when trying to achieve financial wellbeing (Potrich, Vieira, and Da Silva, 2014) [4]. It relates to one's ability to make an informed decision on financial planning, wealth accumulation, debt, and pensions (Lusardi 2015) [5]. Issues related to financial literacy began to emerge in the 1990s. Cutler and Devlin (1996) show that there is an increased need for knowledge related to personal finances, especially for people who are close to retirement age in the United States of America (USA) [6]. This happens because of changes in most social and public-related policies related to old age and finances, such as demographics, social security, and health insurance, as well as pension systems in the USA. The change causes a shift in primary responsibility for the financial welfare and old age from the employer or government to individual responsibility. Findings of the research shows that most individuals are not prepared to accept this responsibility as they do not understand the key components of financial literacy needed to make important decisions that will ensure their financial well-being in old age.

In late 1990s, financial literacy studies identify the importance of personal finance that includes the ability to design financial plan for one self that includes saving and investments schemes. Chen and Volpe (1998) stated that financial literacy is increasingly important which see people to make long-term investment plans for retirement and child education [7]. They also have to decide to save and to take out loans for vacation, pay down home payment, vehicle loans. Morover, they also have to manage health insurance and life insurance needs. Unfortunately, research finds that American society does not have sufficient knowledge related to personal finance. They fail to make the right decisions because they have not received a qualified personal finance education.

Whilst the difference in financial literacy level of developed and emerging countries is not specified, Indonesia seems to rank low in terms of financial literacy. Some agencies conducted surveys related to financial literacy. Among these is Visa's International Financial Literacy Barometer 2012 conducted on 28 countries in Asia, America, Australia and Africa. The results show that Indonesia ranks 27th with a value of 27.7, almost a half of the leading country's (Brazil) level [8]. 


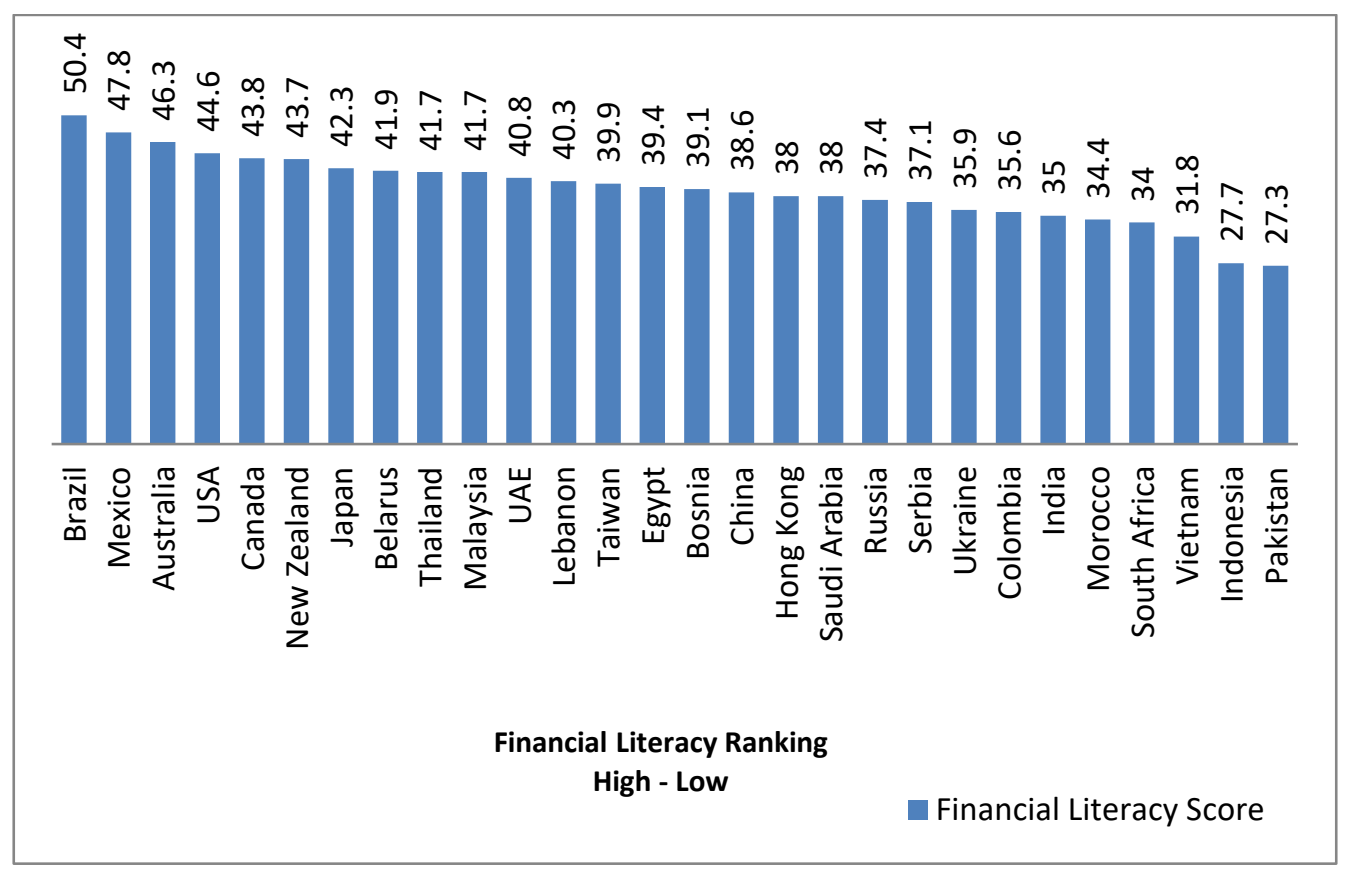

Fig. 1. Financial Literacy Ranking 28 Countries

Other surveys include Financial Literacy around the World: Insight from The Standard and Poor's Ratings Services Global Financial Literacy Survey in 2014 shows that only 25\% -34\% of adults in Indonesia have good financial literacy [9]. Table 1 shows that Indonesia is placed in the high quarter percentile of the scale with 25 to $34 \%$ literacy level together with Thailand, Philippine and PRC.

Table 1. Financial Literacy of Several ASEAN Countries and Surrounding Countries

\begin{tabular}{|c|c|}
\hline Countries & $\begin{array}{c}\text { Financial Literacy } \\
\text { (Scale 0\%-100\%) }\end{array}$ \\
\hline Australia & $55 \%-75 \%$ \\
\hline Myanmar & $45 \%-54 \%$ \\
\hline Japan & $45 \%-54 \%$ \\
\hline Malaysia & $35 \%-44 \%$ \\
\hline Indonesia & $25 \%-34 \%$ \\
\hline Thailand & $25 \%-34 \%$ \\
\hline Philipine & $25 \%-34 \%$ \\
\hline PRC & $25 \%-34 \%$ \\
\hline Vietnam & $0 \%-24 \%$ \\
\hline Cambodia & $0 \%-24 \%$ \\
\hline
\end{tabular}




\begin{tabular}{|c|c|}
\hline India & $0 \%-24 \%$ \\
\hline
\end{tabular}

The survey results are not much different from the survey conducted by the Indonesian Financial Authority (Otoritas Jasa Keuangan, OJK) in 2016. The survey is performed on 9,680 people of which $59.3 \%$ are living in rural area. The (good) financial literacy index for 2016 is $29.7 \%$, a slight increase from $21.8 \%$ in 2013 [10]. Despite the increase, the Indonesian people's knowledge and understanding of financial institutions, products and services are still relatively low and uneven in every sector of the financial services industry. The respondents are most knowledgeable on banking sector $(28.9 \%)$ and the least on capital market sector $(4.4 \%)$. Other financial services included in this survey are insurance, pension fund, financing, and leasing. With regard to this, the research addresses financial literacy in Indonesia, particularly those of young adults.

Researches related to other financial literacy involving young adults are proxied by students in their late study of high school or at the beginning of their higher degree studies. In his research, Chen and Volpe (1998) stated that previous studies involving high school students consistently found that students did not receive a good education regarding the basics of personal finance and had poor financial knowledge [7]. In a study of 1,509 high school students from 63 schools, Mandell (1997) reported an average correct answer score of 57\% on issues in income, money management, savings and investment, and expenditure [11]. The conclusion is that students graduate from school without the ability to make important decisions that affect their lives. Danes and Hira (1987) of 323 students from Iowa State University that include knowledge of credit cards, insurance, personal loans, record keeping, and overall financial management show that students have low knowledge of money management, credit cards and insurance [12]. Volpe, Chen and Pavlicko (1996) conducted a study of 454 students from a public university in the Midwest with a focus on investment knowledge and found that the average true student answer was only $44 \%$ [13]. This shows that they have inadequate knowledge.

In Indonesia itself, the lack of financial literacy level among students has been realized and has been followed up by the government through OJK with its program titled the National Strategy of Financial Literacy of Indonesia (SNLKI) which was inaugurated on November 19, 2013 [10]. In SNLKI 2013, students become the focus of financial literacy activities and a priority target of SNLKI 2013, 2015 and 2018. This study contributes to the scarce body of knowledge on financial literacy amongst young adults in Indonesia and is aimed at first-semester students of three top ranking public universities in Indonesia, namely Universitas Indonesia (UI), Bogor Agricultural University (Institut Pertanian Bogor, IPB) and Bandung Institute of Technology (Institut Teknologi Bandung, ITB).

The selection of the aforementioned universities is based on its scalability potential and representativeness. UI, IPB and PTB have a significant number of enrolled students over the years. In 2017, UI, IPB, and ITB enrolled 6,192, 3,498 and 3,975 students, respectively. These numbers are based on national and privately-conducted enrolment tests for their undergraduate degree programs. It is well-accepted that students in these three universities come from different walks of life and regions across Indonesia, thus appropriately chosen for this research. In addition, we expect the first-semester students to carry the financial knowledge obtained from their secondary education onward to their tertiary education. First-semester students are also considered in bridging period whereby they leave their parents' nest onto being independent in terms of financial 
decision especially since majority of these students come from different regions. This means, the students show a combination of knowledge, attitude and behaviour on finance which are the three dimensions of financial literacy defined by Potrich, Vieira and Kirch (2015) [14].

In this study, we have taken into account the different study field of the students. The reason for the distinction is to capture the bias that might be influenced the results. Indonesian education system polarized field of study at secondary education. Students are obliged to choose either to have science or social major. Although basic knowledge of economy and finance is taught to all students during their first level of secondary school, a more advance knowledge is taught exclusively to social major students on the remaining two years of their study. This selection progresses through their tertiary education, which determines their choice of field of study. Thus, it is necessary to look deeper into the field of study to detect if this tacit knowledge plays into any roles in students' financial literacy at their early stage. Thus, the research is aimed at determining the level of financial literacy amongst first-semester students at UI, IPB and ITB and shed a light on the role of different field of study. The study is significant in twofold. First, it contributes to the limited study of financial literacy amongst young adult in Indonesia. Second, it contributes to the preliminary understanding of the financial literacy of first-semester students with different field of study.

Financial literature refers to a combination of awareness, knowledge, skills, attitudes and behaviours necessary to make sound financial decisions and ultimately achieve individual financial well-being (Atkinson and Messy 2012) [15]. There are three dimensions of financial literacy, namely financial knowledge, financial behaviour and financial attitude. Each of the dimensions is explained below.

1. Financial knowledge. This dimension is related to the basic knowledge of key financial concepts and the ability to apply numerical skills in financial situations. This includes understanding about the subject that affects the ability to manage revenue, expenditure, and savings effectively.

2. Financial behaviour. It is the most important element of financial literacy. These dimensions are related to behaviours that support financial well-being, such as spending planning and the establishment of financial security, as well as other behaviours that can reduce financial well-being, such as excessive use of credit. Good financial literacy is driven by behaviours such as spending planning and building a financial safety net. Conversely, certain behaviours such as excessive use of credit can reduce financial welfare.

3. Financial attitude. This dimension is related to the economic and noneconomic beliefs held by the decision maker over the outcome of a particular behaviour. Therefore, this dimension is a key factor in the personal decision-making process.

This study refers to the definition and dimensions by Atkinson and Messy (2012) as well as Potrich, Vieira and Kirch (2015) as these scholars proposed the same dimensions.

\section{Methodology}

This research applies quantitative approach that aims to determine the level of financial literacy of the selected sample using a pre-determined survey instrument developed by Potrich, Vieira and Kirch (2015) [14]. The questionnaire consists of four parts. The first part is to identify 
the characteristics of respondents. The second part is to indicate the financial attitude of respondents, consisting of 10 questions. The third section is to indicate the financial behaviour of respondents, consisting of 27 questions. The second and third part use a 5-Likert scale. The fourth section is to identify the financial knowledge of respondents, consisting of 13 multiple choice questions with nominal scale answers, where the value of 1 is given if the respondent answered correctly and 0 if the respondent answered incorrectly. Table 2 below shows the conceptual operalization of the aforementioned dimensions.

Table 2. Concept, Dimensions and Indicators

\begin{tabular}{|c|c|c|}
\hline Concept & Dimension & Indicator \\
\hline \multirow{33}{*}{$\begin{array}{l}\text { Financial } \\
\text { Literacy }\end{array}$} & \multirow[t]{10}{*}{ Financial Attitude } & Future goal \\
\hline & & Anxiety towards future finance \\
\hline & & Savings issues \\
\hline & & Anxiety towards financial decision making \\
\hline & & Purchase is based on demand \\
\hline & & Difficulties in planning the spending \\
\hline & & Money disbursement based on priority \\
\hline & & Belief that future is impacted by present financial management \\
\hline & & Satisfaction on spending money \\
\hline & & Perception about money \\
\hline & \multirow{23}{*}{$\begin{array}{l}\text { Financial } \\
\text { Behavior }\end{array}$} & Record keeping and management of personal spending \\
\hline & & Price comparison before purchase \\
\hline & & Monthly saving for future needs \\
\hline & & Spending planning \\
\hline & & Cost identification during credit purchase \\
\hline & & Goal setting is used to guide financial decision \\
\hline & & Goal attainment through financial management \\
\hline & & Family discussion related to personal financial issues \\
\hline & & Timely loan payment \\
\hline & & Saving habit \\
\hline & & Credit purchase habit \\
\hline & & Borrow money to pay instalment \\
\hline & & Before-purchase assessment \\
\hline & & Ability to meet personal spending \\
\hline & & Documentation of personal finance record \\
\hline & & Impulsive buy avoidance \\
\hline & & Credit card's interest rate apprehensiveness \\
\hline & & Saving is done for long-term financial purpose \\
\hline & & Income tax understanding \\
\hline & & Selective investments \\
\hline & & Increase savings when revenue increases \\
\hline & & Ownership of financial reserve \\
\hline & & Annual assets calculation \\
\hline
\end{tabular}




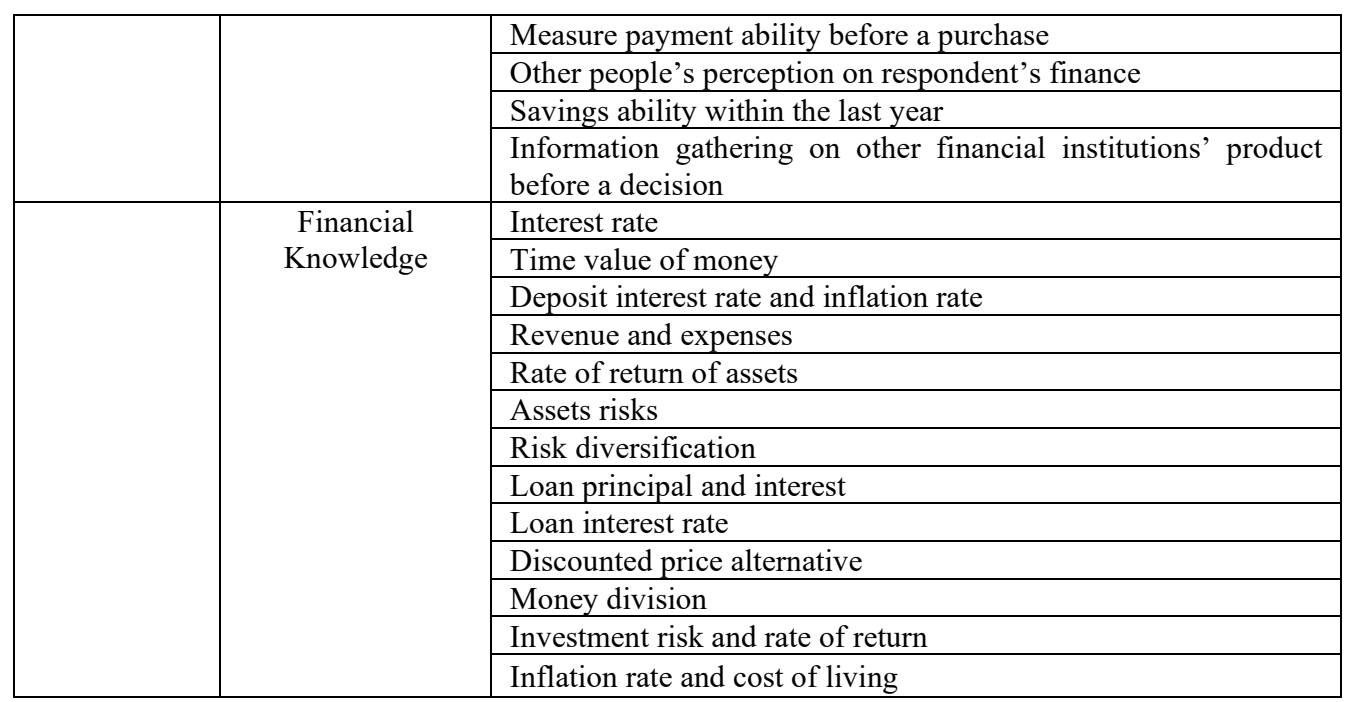

In this study, a univariate analysis using descriptive statistics is used to determine the level of financial literacy of the respondents from UI, IPB, and ITB individually and collectively. In determining the level of financial literacy, method developed by Potrich, Vieira and Kirch (2014) known as the Financial Literacy Thermometer is used. In the Financial Literacy Thermometer, Confirmatory Factor Analysis was used to validate the financial behaviour and financial behaviour dimensions [4]. Next, cluster analysis is used to classify respondents into low or high literacy level. Hierarchical analysis techniques are then applied using Quadratic Euclidean Distance as distance measurements and Ward methods as agglomeration methods (Potrich, Vieira, and Kirch, 2015) [14].

The Financial Literacy Thermometer is measured using below formula:

Financial Attitude:

$$
\mathrm{ATIT}=[0,26 \mathrm{xQ} 2+0,49 \mathrm{xQ} 9+0,25 \mathrm{xQ} 10] / 5
$$

where:

ATIT : Financial Attitude Dimension

Q2 : Question 2

Q9 : Question 3

Q10 : Question 4

Financial Behaviour:

$$
\mathrm{BHVR}=[0,22 \times \mathrm{Q} 13+0,23 \times \mathrm{Q} 20+0,19 \mathrm{xQ} 28+0,15 \mathrm{xQ} 31+0,21 \times \mathrm{Q} 36] / 5
$$

where:

BHVR : Financial Behaviour Dimension Q28 : Question 28 


\begin{tabular}{|c|c|}
\hline Q13 & Question 13 \\
\hline Q20 & Question 20 \\
\hline
\end{tabular}

Financial Knowledge:

$$
\begin{gathered}
\mathrm{KNWL}=[\mathrm{Q} 38+\mathrm{Q} 39+\mathrm{Q} 40+\mathrm{Q} 41+\mathrm{Q} 42+\mathrm{Q} 43+\mathrm{Q} 44+\mathrm{Q} 45+\mathrm{Q} 46+\mathrm{Q} 47+\mathrm{Q} 48+\mathrm{Q} 49 \\
+\mathrm{Q} 50] / 13
\end{gathered}
$$

\begin{tabular}{|c|c|c|c|}
\hline $\begin{array}{l}\text { Where: } \\
\text { KNLW }\end{array}$ & Financial Knowledge Dimension & Q44 & Question 44 \\
\hline Q38 & Question 38 & Q45 & Question 45 \\
\hline Q39 & Question 39 & Q46 & Question 46 \\
\hline Q40 & Question 40 & Q47 & Question 47 \\
\hline Q41 & Question 41 & Q48 & Question 48 \\
\hline Q42 & Question 42 & Q49 & Question 49 \\
\hline Q43 & Question 43 & O50 & Question 50 \\
\hline
\end{tabular}

Insert the result into below formula:

$$
\begin{aligned}
& \mathrm{D}_{0}=(0,49-\mathrm{ATIT})^{2}+(0,55-\mathrm{BHVR})^{2}+(0,57-\mathrm{KNWL})^{2} \\
& \mathrm{D}_{1}=(0,37-\mathrm{ATIT})^{2}+(0,85-\mathrm{BHVR})^{2}+(0,82-\mathrm{KNWL})^{2}
\end{aligned}
$$

Determine the financial literacy level as:

$$
\begin{aligned}
& \text { If } D_{0}>D_{1} \text {, high (good) financial literacy } \\
& \text { If } D_{0}<D_{1} \text {, low (bad) financial literacy }
\end{aligned}
$$

This study is conducted on first-semester students enrolled in UI, IPB, ITB with field of study in Social and Humanities (hereafter termed as "Social") and in Science and Technology (hereafter termed as "Science"). Samples are randomly selected from the three universities. Applying Slovin method, 176 respondents from UI ( 88 Social and 88 Science students), 100 respondents from IPB (50 Social and 50 Science students), and 113 respondents from ITB (57 Social and 56 Science students) were taken as samples. Data from the questionnaire are collected through a face-to-face interview to ensure $100 \%$ response rate and unambiguous answer.

\section{Result and Discussion}

Before the results from the questionnaire are presented, respondents' characteristics are detailed in Table 3 below. Respondents consisted of 176 UI students, 100 IPB students, and 113 ITB students. Out of the 389 respondents, 194 respondents are from the field of Social science and as much as 195 respondents are from the field of Science. All respondents are in the age range of 17 to 19 years. Respondents consisted of 218 male students and 171 female students. From Table 3 it can be seen that the number of respondents from each of the universities are relatively equal in terms of field of study and gender.

Table 3. Respondent Characteristics 


\begin{tabular}{|l|l|r|}
\hline \multicolumn{2}{|c|}{ Characteristics } & Frequency \\
\hline Number of Respondents & UI & 176 \\
\hline & IPB & 100 \\
\hline & ITB & 113 \\
\hline Field of Study & Social & 194 \\
\hline \multirow{2}{*}{ Age } & Science & 195 \\
\hline & $<17$ years old & 0 \\
\hline & $17-19$ years old & 389 \\
\hline \multirow{5}{*}{ Gender } & $>19$ years old & 0 \\
\hline & Male & 218 (Total) \\
& UI & 86 \\
& IPB & 55 \\
& ITB & 77 \\
\hline & Female & 171 (Total) \\
& UI & 90 \\
& IPB & 45 \\
& ITB & 36 \\
\hline
\end{tabular}

Using the aforementioned formula, Table 4 shows the result for each university. The financial literacy level is determined by using the three dimensions collectively.

Table 4. Financial Literacy Level

\begin{tabular}{|c|c|c|c|c|}
\hline Financial Literacy & UI & IPB & ITB & Total \\
\hline Low (\%) & $93(52.8 \%)$ & $61(61 \%)$ & $65(61 \%)$ & 219 \\
\hline High (\%) & $83(47.2 \%)$ & $39(39 \%)$ & $48(39 \%)$ & 170 \\
\hline Total & $176(100 \%)$ & $100(100 \%)$ & $113(100 \%)$ & 389 \\
\hline
\end{tabular}

Table 4 shows the level of student's financial literacy based on three dimensions, namely financial attitude, financial behaviour, and financial knowledge. Out of the 389 respondents, 219 students have low financial literacy level and as many as 170 students have high financial literacy level. Based on the data, it can be concluded that the general trend exists across universities where the number of students with low financial literacy level is higher than those with high financial literacy level. When the result is seen from each university's perspective, it is found that IPB and ITB has the same high portion of low financial literacy level (61\%) compares to UI (52.8\%). This means UI has the highest portion of high financial literacy level (47.2\%) compares to its two other counterparts.

Next, we look into the results with respect to respondents' field of study as shown in Table 5 below. Out of 194 respondents from Social field of study, 78 respondents (40.2\%) have low level of financial literacy and 116 respondents (59.8\%) have high level of financial literacy. When the numbers are analysed further, it can be found that the number of Social students with high level financial literacy is more than that of low financial literacy. This is consistent with the tacit knowledge on economics and finance that they received from their secondary education. 
Table 5. Financial Literacy Level Per Field of Study

\begin{tabular}{|c|c|c|c|c|c|c|c|}
\hline \multirow{2}{*}{$\begin{array}{c}\text { Field of } \\
\text { Study }\end{array}$} & \multicolumn{2}{|c|}{ UI } & \multicolumn{2}{c|}{ IPB } & \multicolumn{2}{c|}{ ITB } & \multirow{2}{*}{ Total } \\
\cline { 2 - 7 } & Low & High & Low & High & Low & High & \\
\hline Social & 37 & 51 & 16 & 34 & 25 & 31 & 194 \\
\hline Science & 56 & 32 & 45 & 5 & 40 & 17 & 195 \\
\hline Total & 93 & 83 & 61 & 39 & 65 & 48 & 389 \\
\hline
\end{tabular}

Out of 195 respondents from Science field of study, 141 respondents (72.3\%) have low level of financial literacy and 54 respondents $(27.7 \%)$ have high level of financial literacy. This means the number of Science students with low level financial literacy is significantly more than that of low financial literacy. The most contrast proportion comes from IPB where $90 \%$ of the Science students have low level of financial literacy as opposed to $10 \%$ of high financial literacy students. This might be caused by the Science nature of the university regardless the fact that IPB have several social science faculties. The least contrast proportion comes from UI where low and high level of Science students' financial literacy is $63.6 \%$ and $37.4 \%$, respectively.

The findings above are consistent with several previous studies that concluded that the field of study taken by the respondent influences the level of financial literacy. Students of Social Studies have greater opportunity to have higher financial literacy compared to those of Science and Technology. Chen and Volpe (1998) concluded that non-business majors tend to lack a good level of financial literacy, whilst Shaari, Hasan, Mohamed and Sabri (2013) found that students of business studies have higher financial literacy than students of non-business studies [7], [16].

When the number is deconstructed further, insights on strong and weak points of the financial literacy dimension of the respondents can be analysed. Table 6 shows that the strongest dimension of financial literacy that the low Social students have is financial attitude. The 0.38 means that respondents have practiced good financial management whereby respondents disagree with the statements. On the other hand, this group of students have not performed well in financial behaviour (value of mean of 0.64 ) whereby respondents' answer show only seldom that they behave consistently as prescribed in the statements. In terms of knowledge, the Social students with low level of financial literacy do not have good financial knowledge (value of mean of 0.5), where they only have half of the questions in the questionnaire correctly.

Table 6. Financial Literacy Dimensions (UI)

\begin{tabular}{|c|c|c|c|c|c|c|c|c|}
\hline \multirow{3}{*}{ Dimension } & \multicolumn{6}{|c|}{ Financial Literacy } \\
\cline { 2 - 9 } & \multicolumn{2}{|c|}{$\begin{array}{c}\text { Low } \\
(\mathbf{n}=\mathbf{3 7})\end{array}$} & \multicolumn{2}{c|}{$\begin{array}{c}\text { High } \\
(\mathbf{n}=\mathbf{5 1})\end{array}$} & \multicolumn{2}{c|}{$\begin{array}{c}\text { Low } \\
(\mathbf{n}=\mathbf{5 6})\end{array}$} & \multicolumn{2}{c|}{$\begin{array}{c}\text { High } \\
(\mathbf{n}=\mathbf{3 2})\end{array}$} \\
\cline { 2 - 9 } & Modus & Mean & Modus & Mean & Modus & Mean & Modus & Mean \\
\cline { 2 - 9 } & 0.42 & 0.38 & 0.40 & 0.37 & 0.40 & 0.43 & 0.40 & 0.32 \\
\hline $\begin{array}{c}\text { Financial } \\
\text { Attitude }\end{array}$ & 0.60 & 0.64 & 0.63 & 0.75 & 0.64 & 0.65 & 0.63 & 0.76 \\
\hline $\begin{array}{c}\text { Financial } \\
\text { Behaviour }\end{array}$ & & & & & & & & \\
\hline
\end{tabular}




\begin{tabular}{|c|c|c|c|c|c|c|c|c|}
\hline $\begin{array}{c}\text { Financial } \\
\text { Knowledge }\end{array}$ & 0.54 & 0.50 & 0.85 & 0.86 & 0.39 & 0.43 & 0.85 & 0.86 \\
\hline
\end{tabular}

As for the Social students with high level of financial literacy, Table 6 shows their strongest dimension lies on the financial knowledge. The mean value of 0.86 means that they answer $86 \%$ of the questions in the questionnaire correctly. This shows good understanding of financial instruments and different settings of financial situations. The weak link of financial literacy dimension for this group of respondents is financial attitude. The 0.37 means that respondents have practiced relatively good financial management. With regard to financial behaviour, the mean value of 0.75 show respondents occasionally behave consistently as prescribed in the statements.

Consistent with the result for the Social students, Table 6 shows that the strongest dimension of Science students with low level of financial literacy lies on the financial attitude. The mean value of 0.38 means that respondents have practiced good financial management whereby respondents disagree with the statements. On the other hand, this group of students have not performed well in financial behaviour which is shown by the similar value as that of Social students in the same cohort (mean value of 0.65 ) whereby respondents' answer show only seldom that they behave consistently as prescribed in the statements. Similar to their counterpart in the same group, the Science students with low level of financial literacy do not have good financial knowledge (value of mean of 0.43), where their correct answer are even less than their counterparts.

As for the Science students with high level of financial literacy, Table 6 shows their strongest dimension lies on the financial knowledge. The mean value of 0.86 means that they answer $86 \%$ of the questions in the questionnaire correctly. This shows good understanding of financial instruments and different settings of financial situations as exactly the same as their Social counterpart who are in the same group. The other two dimensions, namely financial attitude and financial behaviour show 0.32 and 0.76 mean value, respectively. The number refers to good practice of financial management and relatively good financial behaviour where respondents occasionally behave consistently as prescribed in the statements. Essentially, the general pattern occurs for Social and Science students in which those who are categorized in the same group (low or high) have the same strong and weak dimensions of financial literacy.

Table 7. Financial Literacy Dimensions (IPB)

\begin{tabular}{|c|c|c|c|c|c|c|c|c|}
\hline \multirow{4}{*}{ Dimension } & \multicolumn{8}{|c|}{ Financial Literacy } \\
\hline & \multicolumn{4}{|c|}{ Social } & \multicolumn{4}{|c|}{ Science } \\
\hline & \multicolumn{2}{|c|}{$\begin{array}{c}\text { Low } \\
(\mathrm{n}=16) \\
\end{array}$} & \multicolumn{2}{|c|}{$\begin{array}{c}\text { High } \\
(\mathrm{n}=34) \\
\end{array}$} & \multicolumn{2}{|c|}{$\begin{array}{c}\text { Low } \\
(n=45)\end{array}$} & \multicolumn{2}{|c|}{$\begin{array}{l}\text { High } \\
(n=5)\end{array}$} \\
\hline & Modus & Mean & Modus & Mean & Modus & Mean & Modus & Mean \\
\hline $\begin{array}{l}\text { Financial } \\
\text { Attitude }\end{array}$ & 0.60 & 0.45 & 0.25 & 0.34 & 0.55 & 0.43 & 0.45 & 0.37 \\
\hline $\begin{array}{l}\text { Financial } \\
\text { Behaviour }\end{array}$ & 0.63 & 0.67 & 0.63 & 0.77 & 0.64 & 0.68 & 0.87 & 0.82 \\
\hline $\begin{array}{c}\text { Financial } \\
\text { Knowledge }\end{array}$ & 0.39 & 0.40 & 1.00 & 0.88 & 0.54 & 0.52 & 0.85 & 0.82 \\
\hline
\end{tabular}


Table 7 shows the analysis for IPB students. As with the cohort from UI, the strongest dimension of financial literacy that the low Social students have is financial attitude. The 0.45 means that respondents have practiced relatively good financial management whereby respondents disagree and ignorant with the statements. On the other hand, this group of students have not performed well in financial behaviour (value of mean of 0.66) whereby respondents' answer show only seldom that they behave consistently as prescribed in the statements. In terms of knowledge, the Social students with low level of financial literacy do not have good financial knowledge (value of mean of 0.40), where they only have half of the questions in the questionnaire correctly.

As for the Social students with high level of financial literacy, Table 7 shows their strongest dimension lies on the financial knowledge. The mean value of 0.88 means that they answer $88 \%$ of the questions in the questionnaire correctly. This shows good understanding of financial instruments and different settings of financial situations. The weak link of financial literacy dimension for this group of respondents is financial attitude. The 0.34 means that respondents have practiced relatively good financial management. With regard to financial behaviour, the mean value of 0.77 show respondents occasionally behave consistently as prescribed in the statements.

Consistent with the result for the Social students, Table 7 shows that the strongest dimension of Science students with low level of financial literacy lies on the financial attitude. The mean value of 0.43 means that respondents have practiced relatively good financial management whereby respondents disagree with the statements. On the other hand, this group of students have not performed well in financial behaviour which is shown by the similar value as that of Social students in the same cohort (mean value of 0.68 to 0.66 for Social students) whereby respondents' answer show only seldom that they behave consistently as prescribed in the statements. Only performed slightly better than their counterpart in the same group, the Science students with low level of financial literacy also categorized as do not have good financial knowledge (value of mean of 0.52 ), where their correct answer are only half of the number of the questions.

As for the Science students with high level of financial literacy, Table 7 shows the same pattern as the same cohort from Social students where their strongest dimension lies on the financial knowledge. The mean value of 0.82 means that they answer $82 \%$ of the questions in the questionnaire correctly. This shows good understanding of financial instruments and different settings of financial situations as exactly the same as their Social counterpart who are in the same group. The other two dimensions, namely financial attitude and financial behaviour show 0.37 and 0.82 mean value, respectively. The number refers to relatively good practice of financial management and relatively good financial behaviour where respondents frequently behave consistently as prescribed in the statements. Essentially, the general pattern occurs for Social and Science students in which those who are categorized in the same group (low or high) have the same strong and weak dimensions of financial literacy.

Table 8 below shows the same analysis for ITB students and show similar pattern as the other universities. Such as their cohort from Social field of study from UI and IPB, the strongest dimension of financial literacy of the low Social students is financial attitude. The 0.42 means that respondents have practiced relatively good financial management whereby respondents disagree with the statements. On the other hand, this group of students have not performed well in financial behaviour (value of mean of 0.68) whereby respondents' answer show only seldom that they 
behave consistently as prescribed in the statements. In terms of knowledge, the Social students with low level of financial literacy do not have good financial knowledge (value of mean of 0.40 ), where they only have less than half of the questions in the questionnaire correctly.

Table 8. Financial Literacy Dimensions (ITB)

\begin{tabular}{|c|c|c|c|c|c|c|c|c|}
\hline \multirow{4}{*}{ Dimension } & \multicolumn{8}{|c|}{ Financial Literacy } \\
\hline & \multicolumn{4}{|c|}{ Social } & \multicolumn{4}{|c|}{ Science } \\
\hline & \multicolumn{2}{|c|}{$\begin{array}{c}\text { Low } \\
(\mathrm{n}=\mathbf{2 5})\end{array}$} & \multicolumn{2}{|c|}{$\begin{array}{c}\text { High } \\
(\mathbf{n}=\mathbf{3 1})\end{array}$} & \multicolumn{2}{|c|}{$\begin{array}{c}\text { Low } \\
(n=40)\end{array}$} & \multicolumn{2}{|c|}{$\begin{array}{c}\text { High } \\
(\mathrm{n}=17)\end{array}$} \\
\hline & Modus & Mean & Modus & Mean & Modus & Mean & Modus & Mean \\
\hline $\begin{array}{c}\text { Financial } \\
\text { Attitude }\end{array}$ & 0.40 & 0.42 & 0.40 & 0.34 & 0.50 & 0.42 & 0.40 & 0.37 \\
\hline $\begin{array}{l}\text { Financial } \\
\text { Behaviour }\end{array}$ & 0.67 & 0.68 & 0.63 & 0.79 & 0.64 & 0.68 & 0.63 & 0.76 \\
\hline $\begin{array}{c}\text { Financial } \\
\text { Knowledge }\end{array}$ & 0.39 & 0.40 & 0.85 & 0.87 & 0.39 & 0.46 & 0.85 & 0.86 \\
\hline
\end{tabular}

As for the Social students with high level of financial literacy, Table 8 shows their strongest dimension lies on the financial knowledge. The mean value of 0.87 means that they answer $87 \%$ of the questions in the questionnaire correctly. This shows good understanding of financial instruments and different settings of financial situations. The weak link of financial literacy dimension for this group of respondents is financial attitude. The 0.34 means that respondents have practiced relatively good financial management. This value is exactly the same as those cohort at IPB. With regard to financial behaviour, the mean value of 0.79 shows respondents occasionally behave consistently as prescribed in the statements.

Consistent with the result for the cohort of Social students from UI and IPB, Table 8 shows that the strongest dimension of Science students with low level of financial literacy lies on the financial attitude. The mean value of 0.42 means that respondents have practiced relatively good financial management whereby respondents disagree with the statements. On the other hand, this group of students have not performed well in financial behaviour which is shown by the similar value as that of Social students from IPB in the same cohort (mean value of 0.68 ) whereby respondents' answer show only seldom that they behave consistently as prescribed in the statements. The Science students with low level of financial literacy also categorized as do not have good financial knowledge (value of mean of 0.46 ), where their correct answer are less than half of the number of the questions.

As for the Science students with high level of financial literacy, Table 8 shows the same pattern as the same cohort from Social students from UI and IPB where their strongest dimension lies on the financial knowledge. The mean value of 0.86 means that they answer $86 \%$ ( 11 out of 13 questions) of the questions in the questionnaire correctly. This shows good understanding of financial instruments and different settings of financial situations as exactly the same as their Social counterpart who are in the same group. The other two dimensions, namely financial attitude and financial behaviour show 0.37 and 0.76 mean value, respectively. The number refers to relatively good practice of financial management and relatively good financial behaviour where 
respondents frequently behave consistently as prescribed in the statements. Essentially, the general pattern occurs for Social and Science students in which those who are categorized in the same group (low or high) have the same strong and weak dimensions of financial literacy.

Based on the above discussion, it can be concluded that a general pattern exists across cohorts. Students who study Social are in general have better financial literacy compares to those who study Science. With regard to financial literacy dimensions, financial knowledge is the strongest dimension that the high-level cohort has regardless of their field of study. The low-level cohort shows strongest point in financial attitude and weakest point in financial knowledge. This suggests that low level of financial literacy is marked by the low financial knowledge. Using the findings of this study, it is necessary to scaffold efforts to achieve financial inclusion initially through education and information dissemination about financial products and schemes.

\section{Conclusion}

Financial literacy plays a critical role to ensure financial inclusion in the digital economy era. This is to overcome technical and infrastructure issues related to the outreach of financial access. To measure the level of financial literacy, three dimensions are necessary. These are financial attitude, financial behaviour and financial knowledge. Although the level of financial literacy in Indonesia has risen in 2016 from where it was in 2013, there are things still to be done in this area. This study addresses the issue of financial literacy amongst first-semester students at UI, IPB, and ITB. Based on the results of data analysis, the conclusions that can be drawn are as follows: (1) the number of students with low literacy level is greater than the frequency of students with high literacy levels for all three universities; (2) students who are studying Social study are likely to have higher level of financial literacy than those studying Science; (3) the low-level financial literacy students from Social and Science field of study are marked by relatively good financial attitude and behaviour but do not have good financial knowledge; and (4) the high-level financial literacy students from Social and Science field of study are marked by good financial knowledge. This study contributes to the scarce study on financial literacy amongst young adults in Indonesia. It also shed light on the different level of financial literacy based on field of study as well as the featured dimension that marks each cohort. For future research, it would be advised to conduct a longitudinal study on financial literacy amongst young adults to refine government's efforts to achieve financial inclusion.

\section{References}

[1] Tapscott, D.: The Digital Economy: Promise and Peril in the Age of Networked Intelligence. USA: Mc-Graw Hill (1995)

[2] Ozili, P. K.: Impact of Digital Finance on Financial Inclusion and Stability. Borsa Istanbul Review, Article in Press (2018)

[3] Asian Development Bank: Accelerating Financial Inclusion in South-east Asia with Digital Finance. Asian Development Bank Technical Report (2016)

[4] Potrich, Ani Caroline Grigion., Vieira, Kelmara Mendes., and Da Silva, Wesley Mendes.: Development of A Financial Literacy Model for University Students. Management Research Review, 39 (3), 356-376 (2014) 
[5] Lusardi, A.: Financial Literacy: Do People Know the ABCs of Finance? Public Understanding of Science, 24(3), 260-271 (2015)

[6] Cutler, N.E., and Devlin, S.J.: Financial Literacy 2000. Journal of the American Society of CLU\&ChFC (1996)

[7] Chen, H., and Volpe, R.P.: An Analysis of Personal Financial Literacy Among College Students. Financial Series Review, 7 (2), 107-128 (1998)

[8] Visa: Visa's International Financial Literacy: Barometer 2012. (n.d.). 21 September 2017.http://www.africamoneyskills.com/downloads/FL_Barometer_Final\%20Apr\%2020 12.pdf (2012)

[9] Financial Literacy around the World: Insight from The Standard and Poor's Ratings Services Global Financial Literacy Survey (2014)

[10] Otoritas Jasa Keuangan. Survei Nasional Literasi dan Inklusi Keuangan 2016. (n.d.). 21 September $2017 . \quad$ http://www.ojk.go.id/id/berita-dan-kegiatan/siaranpers/Documents/Pages/Siaran-Pers-OJK-Indeks-Literasi-dan-Inklusi-KeuanganMeningkat $/ 17.01 .23 \% 20$ Tayangan $\% 20 \% 20$ Presscon $\% 20 \% 20$ nett.compressed.pdf

[11] Mandell, L. Personal Financial Survey of High School Seniors. Jump Start Coalition for Personal Financial Literacy p. 7 (1997)

[12]Danes, Sharon M., and Hira, Tahira K.: Money Management Knowledge of College Students. Journal of Student Financial Aid. Vol. 17: Iss. 1, Article 1 (1987)

[13] Volpe, R.P., Chen, H. and Pavlicko, J.J.: Personal Investment Literacy Among College Students: A Survey. Financial Practice and Education (1996)

[14]Potrich, Ani Caroline Grigion., Vieira, Kelmara Mendes., and Kirch, Guilherme.: Determinants of Financial Literacy: Analysis of the Influence of Socioeconomic and Demographic Variables. RevistaContabilidade\&Financas, 26 (96), 362-377 (2015)

[15] Atkinson, A., and Messy, F.: Measuring Financial Literacy: Result of the OECD/International Network on Financial Education (INFE) Pilot Study. OECD Working Paper on Finance, Insurance, and Private Pensions, 15 (2012)

[16] Shaari, N.A., Hasan, N.A., Mohamed, R.K.M.H., Sabri, M.A.J.: Financial Literacy: A Study Among the University Students. Interdisciplinary Journal of Contemporary Research in Business, 2 (2), 279-299 (2013) 